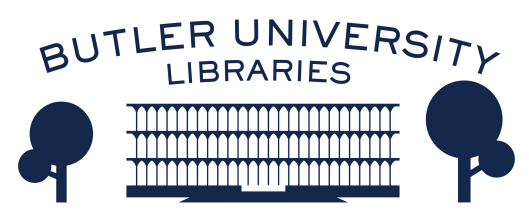

Journal of Hindu-Christian Studies

Volume 6

Article 9

January 1993

\title{
Environmental Ethics: Ancient Traditions and Contemporary \\ Dilemmas: A Hindu Perspective
}

Sehdev Kumar

Aaloka Mehndiratta

Follow this and additional works at: https://digitalcommons.butler.edu/jhcs

Part of the Religion Commons

\section{Recommended Citation}

Kumar, Sehdev and Mehndiratta, Aaloka (1993) "Environmental Ethics: Ancient Traditions and Contemporary Dilemmas: A Hindu Perspective," Journal of Hindu-Christian Studies: Vol. 6, Article 9. Available at: https://doi.org/10.7825/2164-6279.1078

The Journal of Hindu-Christian Studies is a publication of the Society for Hindu-Christian Studies. The digital version is made available by Digital Commons @ Butler University. For questions about the Journal or the Society, please contact cbauman@butler.edu. For more information about Digital Commons @ Butler University, please contact digitalscholarship@butler.edu. 


\title{
Environmental Ethics:
}

\section{Ancient Traditions and Contemporary Dilemmas:}

\author{
A Hindu Perspective
}

\author{
Sehdev Kumar* and Aaloka Mehndiratta** \\ *University of Waterloo $\quad{ }^{* *}$ Aaloka Dance School, Kitchener
}

\begin{abstract}
ACCORDING TO AN ancient Hindu myth the goddess Earth was once imprisoned at the bottom of the ocean, in the nether world, by a demon who had laid waste to the earth, causing havoc to the order of things. To rescue her from the demon, Lord Vishnu incarnated as a boar, as Varaha Avatar. He fought and killed the demon and released the goddess Earth by carrying her on his tusk to float free once more on the cosmic waters.
\end{abstract}

This myth, with its allusions to the demonic forces that destroy the harmony of the universe and the intervention of gods to restore it, is deeply ingrained in the Hindu psyche. This, and other myths and legends with similar allusions, have been portrayed in Indian art, sculpture, dance and poetry for the past two millennia; one of the places where Varaha Avatar is sculpted is a fourth-century massive rock-relief at Udaigiri in Madhya Pradesh.

Today, when the harmony of the universe is deeply disturbed and the goddess Earth seems critically endangered, the people of India, like people everywhere, are once again in search of new myths and new gods to rescue the imperiled earth. The Varaha Avatar, however, will have to assume a different form this time.

The earth is our home; amongst countless billions of heavenly bodies this 'little speck of dirt' seems to be the only place in this vast universe where life, in its myriad forms, has evolved and where it thrives. The earth is the womb of the universe; it is our mother - it gives birth, it nourishes, it consoles in grief, it receives in death. For centuries the Indian poets and sages have sung in its praise, invoking awe and wonder:

Truth, unyielding cosmic order, consecration,

Ardour and Prayer and Holy Ritual

Uphold the Earth, May she the ruling Mistress

of what has been and what will come to be,

for us spread wide a limitless domain. 1

With all her munificence Mother Earth is, nevertheless, not always benevolent; sometimes she is wild and unyielding, chaotic and vengeful. But she is always there offering us a home we can call our own: 
The Earth on whom waters flow day and night, never ceasing motion - the earth that is brown

black and red in colour, a vast abode. $^{2}$

The Earth is our home and our mother, but for a Hindu it is not inert; it is not a house of brick and mortar, nor is it a mother made of plastic. It breathes, it evolves, it is conscious. It creates, it destroys, it recreates. The earth mediates between humans and the unyielding cosmic order inherent in nature; the eternal bond between humans and nature is nourished by the law of rta - universal harmony, satya - truth and prayers:

Whatever, I dig of you, O Earth,

May that grow quickly upon you,

O Pure One, may my thrust never pierce thy

Vital points, thy heart. ${ }^{3}$

These are some of the religio-philosophical thoughts about the man-nature relationship that have been at the core of Hindu mythology and ritual as well as poetic and artistic creations. The nobility of these thoughts evince a pervasive sense of sanctity in all aspects of nature. For a Hindu the rivers and lakes are sacred; forests and mountains are deemed the abode of gods; trees and flowers are considered integral parts of the 'sacred geography'. Kalpavriksha the wish-fulfilling tree - is a major motif in Indian literature and art; pots of gold and bags of precious gems are believed to lay at its roots. This mythical sacred tree is surrounded by the Seven Treasures, the conch and the lotus among them, and it has the power to bestow all precious things. There is also kalpavalli - wish-fulfilling creeper - in whose tendrils jewels, flowers, pots of fragrant wine, and lovely garments of exquisite pattern are embedded. This meandering vine is sculpted in the Bharhut rail, 2nd century $\mathrm{BCE}$, as also in the ceilings of many domes in the Jain temples at Mount Abu, 10th-13th century CE.

In India trees have been thought of as almost human companions, capable of sexual activity. Hence there was a mating of trees and creepers, and a marriage of beloved ones. This explains the development of the concept of dohadathe power of a young girl to make a plant bloom out of season.

There is thus an all-pervasive ethos amongst the Hindus that sees the animal and the human world as one unbroken continuum. This is expressed in numerous ways in Hindu art and sculpture: the Hindu gods and goddesses, and the whole pantheon of Hinduism and the Jain tirthankaras have one or the other animal, flower or tree symbolically associated with them; sometimes these symbols are amongst the most significant features distinguishing one tirthankara from another. The Hindu devis and devas; and avatars have their animal vahan - a mode of transport that takes them to distant corners of the universe. As mediums for the power of the gods, these vahans are often as sacred as the gods themselves. Lord Shiva's vahan is nandin - the sacred bull; Vishnu is garuda - half man, half eagle; Brahma's is hans - the pure white swan, which is also the vahan of Saraswati, the goddess of knowledge and the arts. In one remarkable nineteenth-century painting, Lord Brahma goes to the swan to seek knowledge; the swan - paramhans - has thus come to be regarded as a symbol of transcendental knowledge and purity. Similarly, Durga, the goddess of valour, rides a lion, as does Ambika, the goddess of fecundity. Lakshmi, the goddess of wealth and prosperity, is often portrayed as accompanied by elephants, pouring cosmic waters over her. Lord Ganesha ganapati - is 'the custodian of all beings'; he himself is half man, half elephant; his vahan is a mouse. 
The Indian artistic and religious tradition finds the undivided Self in every living thing, even in the inanimate, thus recognising - even sometimes exaggerating - the essential likeness of animals and humans. Indian art is inspired, as Coomaraswami has observed,

with the deep conviction that human and animal life differs only in degree, and that all must travel on the same road towards the same goal of ultimate knowledge of the Brahman. Animate and inanimate alike must be sensitive to the accomplishment of spiritual purposes. It is with deep sincerity, rather than conscious humour, that Indian animals are made to play the part of men, and often to surpass their human fellows in nobility and faith. ${ }^{4}$

The Indian tradition is, however, different from Chinese art where landscape is regarded as the highest theme, and its constant aim is to lead man's thought from the self into the universal life around him. Hindu thought may see undivided Self in all things, but it is, all the same, anthropocentric.

The birds and deer are symbols of general ideas, and landscape is always background for the human or divine actors. ${ }^{5}$

On the ladder of life and divinity, human life is the highest for the Hindu: again and again Hindu tradition celebrates human existence as the pinnacle of all life; in the cycle of births and rebirths, human life is invariably supreme:

Kabir manas janam durlabh hai

On the wheel of time

Human life appears

Only rarely

Rejoice, as it lasts,

O Kabir!

A fruit once ripened

And fallen to the ground,
Can't be attached

To the branch again. 6

Tat tvam asi - 'That art Thou' - the essence of Upanishadic vision is in fact a celebration of man touching the transcendent gods and immanent nature all at once, and in equal measures. The idea of reincarnation, based as it is on one's Karmic configurations, is central to Jain, Buddhist and Hindu thought. This idea places man on the highest rung of the evolutionary ladder, but it recognises, of necessity, that human life is continually dissolving and resolving, like the waves in the sea. There are troughs and crests, but the essence of the wave is still the water. Hence, whatever anything is in its manifested form at any stage of its being, it is always the representation of One.

In this view of nature and man's place in it, there is no mention of the Ascent or the Descent of Man, ideas so dear to the Man of Progress. There is, instead, only the notion of being and becoming; all things are 'struggling' to become what they really are: the seed struggling to become an apple; the caterpillar struggling to become a butterfly; the pearl in the oyster struggling to become perfectly round and radiant. And man too struggling to become man. Each and everything in the universe is engaged in the unfolding of its own unique destiny, its swadharma.

In all cultural traditions the notion of One in Many and All in One has been honed and chastened, to various degrees, by a certain mystical vision. Amongst the Indians, however, it is an all-pervasive notion; its roots go deep and far like the legendary banyan tree of India. Thus, for the Indians, there is nothing in nature that is not touched, at one point or another, by the same consciousness that resides in man and the gods. As such, there are sacred rivers, mountains and animals; trees are sacred no less than the 
birds and the flowers. And they, in turn, are continually evolving and yearning to return to the source, knowing, as Thomas Hardy suggested, that they are all 'but one mask of many worn by the Great Face behind'.

Purusha and Prakriti - 'manifold nature eternally fructified' - are the warp and weft of Indian aesthetics and spiritual seeking; it has been at the core of a Hindu's worldview. In this worldview nature is both manifested and symbolic. But its symbols and their message, though sometimes classified and interpreted, are in fact always somewhat elusive and veiled. One can hope to decipher from these mysterious hieroglyphics of nature only those secrets that one's own deepest consciousness possesses the power to endow with meaning. Thus in the Indian myth and iconography there is an exploration of an 'inner nature' as there is of an 'outer nature', both at the same time.

This is perhaps best illustrated by the symbolic significance of the various avatars of Lord Vishnu, the sustainer of harmony and order of the universe. As he assumes many incarnations each is indicative of an evolutionary process of life: as matsya avatar, Vishnu is a fish, a creature of the water; then he is kurma a tortoise, a water animal that can negotiate land as well; then he moves to land as varaha, a boar; then he is Narasimha avatar - half man, half lion. Later on, as Vamana, a dwarf, Vishnu is human but not quite fully developed. And then there are other avatars - of Parshurama, Rama and Krishna. Thus Lord Vishnu is animal, man and god, all in one. In the Indian tradition, thus, all life is continually evolving, perpetually becoming, always perfect, an avatar at each stage, and yet ceaselessly metamorphosing.

Even though human life is considered supreme, a sense of stewardship of the animal kingdom by humans runs deep in the Hindu mind. Even today, throughout the length and breadth of India, when a man or a woman sits down to eat, a symbolic connection with the universe and all its creatures is reasserted: a few grains of rice are left beside the banana leaf or a thali for the ants or a squirrel to eat; a piece of bread for the dog, some food for the cow; water is poured in the tulsi pot; offerings are made to the sun. However meagre a man's meal is, he is nevertheless a keeper and a custodian of the earth. $\mathrm{He}$ is Pashupati; he imbibes the spirit of Shiva.

The idea of Pashupati - 'the benevolent custodian of the animal world' - was first expressed in India about 2000 BCE in the famous Mohenjodaro seal of the horned and seated figure surrounded by animals. Later Lord Shiva is referred to as Pashupati. The figure of a deer in one of his hands, or the venomenous snakes coiled around his neck, show him as the 'Lord of the Animal Kingdom'. Similarly, Krishna is known as the protector of cows and bulls; as Gopala he is the 'keeper of cows'. Like Christ - the Good Shepherd - Buddha is waited upon by all animals in the forest with great devotion and reverence; in early representations, as on the magnificent gateways of Sanchi (1st2nd century BCE), Buddha is worshipped not as a man but as a tree The Tree of Enlightenment.

Hindu temples 'dedicated to Hanuman are scattered all over India, some on mountain tops and deep in forests. Hanuman, the great devotee of Lord Rama, is half man and half monkey. Because of his profound devotion to Rama, he is also god-like. As such monkeys in India are regarded as. personifications of Hanuman; they are to be seen everywhere, particularly in the Hanuman temples, greatly venerated and indulged by the worshippers.

Even as lowly and abject a creature as a rat has found a special place in the 
Indian scheme of things. In the famous 19th-century Deshnok Karni Mata Temple near the city of Bikaner in the state of Rajastan, thousands of rats wander all over with utter abandon as they are fed and adored by the worshippers as sacred 'future bards'.

What marks this belief in the sanctity of nature, in all its varied manifestations, is the notion of Prana - the life principle of harmony, order and inter-relatedness of all creation. The idea of Prana as 'cosmic 'breath' has been most poignantly expressed by the fifteenth-century sage-poet Kabir:

This or that...

But in truth

It is One Element

That permeates

Everywhere!

Many different bodies

But it is

One breath

That blows

In all beings! 7

It is in this spirit, to take that 'cosmic breath', that a Hindu goes on a pilgrimage to various tirthas - sacred fords or 'crossings', dhams - divine 'abodes, or pithas - places of the divine. In India there are thousands of such places, creating a sense of divyabhumi 'sacred ground'- for the entire country. Such a place is meant for more than human activity; a tirtha on the Indian soil is a potent place, a natural epiphany of the divine. At such a place

the gods are seen at play .. the gods always play where lakes are, where the sun's rays are warded off by umbrellas of lotus leaf clusters, and where clear water paths are made by swan ... the gods always play where groves are near rivers, mountains and springs, and in towns with pleasure gardens. ${ }^{8}$

One may be tempted to conclude from the above that in its every-day existence Hindu life and culture are continually chastened and guided by these mythopoetic references. Sadly this is not so; far from it. Our contemporary concerns for pollution and purity have in fact been deeply inherent in the life and social structure of Hinduism almost from its very beginning. Ideas of purity and pollution, and various kinds of polluting factors, are extensively treated in the Hindu scriptures and the law books. In a Hindu society,
the network of purity and pollution is thorough, generally consistent in detail within its terms, and perme- ates every conceivable aspect of life. Nothing is impermeable to pollution: no person, no thing, no act ... whereas Western society conceives the business of eliminat- ing dirt to be a matter of aesthetics and hygiene, Indian society is primarily concerned with sacred contagion and dread of pollution by members of society who are specialists in the elimination of impurity. ${ }^{9}$

There are both permanent and temporary pollutions. Whereas forms of temporary pollution can be overcome by ritual purification, as by the sprinkling of water, or a ritual bath, a temple rite, or a penance, permanent pollution is both collective and hereditary. This is reflected in the graded status of specialised castes engaged in polluting work, such as leather-makers, barbers, launderers, sweepers, and funeral attendants.

The very existence and frequent use of the English word 'untouchable' (asprcya in Sanskrit) reflects this preoccupation with pollution and purity. In particular food as a magical substance with the power to modify social relations amongst the Hindus, through rapidly changing, has been of special significance. Who may receive food and water from whom without incurring pollution has been at the base of caste ranking in 
Hindu society. To receive food from another is to share, to a degree, in that other's nature. And hence elaborate rules and codes of conduct exist within and between castes about what food can be shared by whom and to what degree.

There are also other gradations of food according to degrees of nourishment and spiritual quality: sattva (pertaining to light, spirituality, subtlety) - food fit for the Brahmans; rajas (pertaining to the passions, energy, physical vitality and strength) - food for Kshatryas and Vaishyas, and tamas (pertaining to darkness, lethargy, stupidity, heaviness) food for Shudras and untouchables. The high affect and dread of tamas has a peculiarly Indian connotation; in the words of Nirad Chaudhuri:

It was the perpetual sight of an oozing of uncleanliness into the unconsciousness, taken with the visible fact of the proneness of all things to decompose in a tropical country, that created the characteristic Hindu concept of tamas, as the lowest of gunas or attributes. The word tamas literally means darkness, but in Hindu thought and feeling it stands really for a very comprehensive term for all kinds of squalor - material, biological, intellectual, moral, and spiritual. Suffering in tamas was the Hindu hubris. 10

The practices and ideas about pollution, purity and untouchability, as they have impinged on the social values and institutions of Hindu society, have had disastrous results reflecting debilitating human behaviour. Such practices contrast sharply, often in complete contradiction, with a poetic and spiritual Hindu worldview of nature, as briefly presented above.

The rigid social stratifications amongst the Hindus, in fact, have tended to place those who work with the raw elements of nature - peasants, fishermen, stone-cutters, carpenters, potters, weavers, basket makers, leather workers, wood gatherers - at the lowest rung of the social hierarchy. Hence living everyday encounters of such people with nature have received scant attention.

As a member of the world community, for a Hindu too, human survival, from its earliest beginnings, has been a form of combat with nature. Nowhere in the world has nature yielded its fruit or revealed its secrets to humans without struggle or ingenuity.

In Nectar is a Sieve - a modern Indian novel of classical proportions Kamala Markandaya describes the fate of a peasant family struggling to eke out an existence from an unyielding piece of land:

That year the rains failed. A week went by, two. We stared at the cruel sky, calm, blue, indifferent to our need. We threw ourselves on the earth and we prayed. I took a pumpkin and a few grains of rice to my goddess, and I wept at her feet. I thought she looked at me with compassion and I went away comforted, but no rain came. ${ }^{11}$

As hunger stalks the children and the impoverished, and death and despair lurk all around the village, there is a reflection on the 'nature' of nature itself:

Nature is like a wild animal that you have trained to work for you. So long as you are vigilant and walk warily with thought and care, so long it will give you its aid; but look away for an instant, be heedless or forgetful, and it has you by the throat. 12

These words speak for all those whose lives depend intimately and directly on the bounties of nature. The environmental crisis that now looms all over the world has pushed people like these to the edge of existence, making them into 'environmental refugees'. It is 
their fate that has made it imperative for all of us to ask questions about environmental ethics, man-nature relationships, and about traditional ecological practices that were integral to sustainability.

The onslaught of modernisation and of unprecedented demands by a huge and increasing population on all elements of nature - has challenged a Hindu's cosmology as much, and as profoundly, as it has done for people of all traditional faiths. Thus at present a Hindu too is groping for a new relationship with nature that integrates what is nourishing in his tradition with a modern temper for social justice and human rights. His spiritual and artistic insights cannot stand aloof from scientific knowledge of nature and from modern technology, with their extraordinary capacity to transform nature, and to use and abuse it. The environmental crisis in India is as acute, even worse, as it is in any other part of the world. The Hindu mythic and spiritual ethos provides an exalting understanding of man's place in the universe, and they offer guiding principles for man-nature relationships that are both noble and ennobling. But. do they - or even more importantly, can they and should they - create a blueprint for modern environmental ethics that must address questions of social and resource-use equity, massive poverty and unfulfilled expectations? In short, how does a spiritual vision become a radical political process where the ecstasies of the soul and the suffering of the body are seen all of one piece?

\section{Notes}

1. Atharva Veda 12.1.1, R. Panikker (tr.), Vedic Experience, Delhi: Mantamanjari, 1977.

2. Ibid. $12.19 \mathrm{a}-11 \mathrm{~b}$.

3. Ibid. 12-35.

4. Ananda Coomeraswamy, Rajput Painting, Vol.1, Delhi: Motilal Banarsidass, 1976, p. 72 .

5. Ibid.

6. Kabir, Sehdev Kumar (tr.), The Vision of Kabir, Concord: Alpha \& Omega; 1984 , vii.6.

7. Ibid. xii.6.

8. For a detailed discussion on this theme, see S. Kramrisch, The Hindu Temple, Vol.1, Delhi: Motilal Banarsidass, 1976, pp.4-7.

9. R. Lannoy, The Speaking Tree, London: Oxford University Press, 1975, p.148.

10. N.C. Chaudhuri, The Continent of Circe, London: Chatto and Windus, 1965, p.171.

11. Kamala Markandaya, Nectar in a Sieve, New York: Bantam, 1954, p.76.

12. Ibid. p.43. 